JEL Classification: F 01; F 02; M 31

UDC 339.9.012.23:339.138

DOI: $10.30857 / 2415-3206.2019 .2 .1$

\section{INTERNATIONAL MARKETING AND MARKETING AUDIT IN THE CONTEXT OF EUROPEAN INTEGRATION AND GLOBALIZATION}

\author{
O. ZYMA' ${ }^{1}$, O. PTASHCHENKO', \\ I. SHEVCHENKO ${ }^{1}$, O. AFANASIEVA ${ }^{1}$ \\ ${ }^{1}$ Simon Kuznets Kharkiv National University of \\ Economics, Ukraine
}

Introduction. Features of international marketing are determined by the specific environment in which it is implemented. First of all, it is necessary to take into account the attitude of the national government to foreign economic activity. It can create favorable conditions for carrying out foreign economic activities. Conversely, the government may be uninterested in the entry of its individual firms into the foreign market, and may create all sorts of obstacles along the way. Marketing in general and international marketing today is characterized by the rapid aging of ideas and concepts caused by the changing market situation. And the company management system is inertial: the marketing strategies, methods and techniques used yesterday are still in use today. Therefore, it is useful to involve third parties to conduct a marketing audit, which allows you to take a fresh look at the usual circumstances and conditions, bring in new ideas and open up new opportunities.

The hypothesis. It is assumed that the processes of globalization have a significant impact not only on the development of international marketing, but also on marketing audit, which in turn allows to determine the features of international marketing.

The aim of the article is a study of the essence of international marketing and marketing audit, presents their main characteristics and principles of interaction in modern business conditions.

The research methodology: method of systematic analysis and logical generalization
- for implementation of directions of development of international marketing; substrate approach - to justify and systematize the features of international marketing and marketing audit.

Results: Features of international marketing and marketing audit are substantiated, it allows to evaluate the activity of the enterprise in the sphere of marketing and international marketing, to compare the obtained data on the marketing activity of the enterprise in the domestic and foreign markets with the approach to the marketing of direct competitors, to develop recommendations for increasing the efficiency of marketing division, on the use of modern marketing tools and features of international marketing and to determine the algorithm their implementation to meet the new requirements of the market and the competitive situation, to evaluate the effectiveness of existing staff of marketing, make personnel decisions, identify qualitative and quantitative needs for staff.

Conclusions: the question of conducting a marketing audit in today's conditions of functioning of enterprises is of the highest priority. Its need is to determine the effectiveness of existing management methods, as well as to develop new approaches to creating a complex marketing within the enterprise strategy, which operates in the context of European integration and globalization processes.

Keywords: marketing; international marketing; marketing audit; marketing audit. 


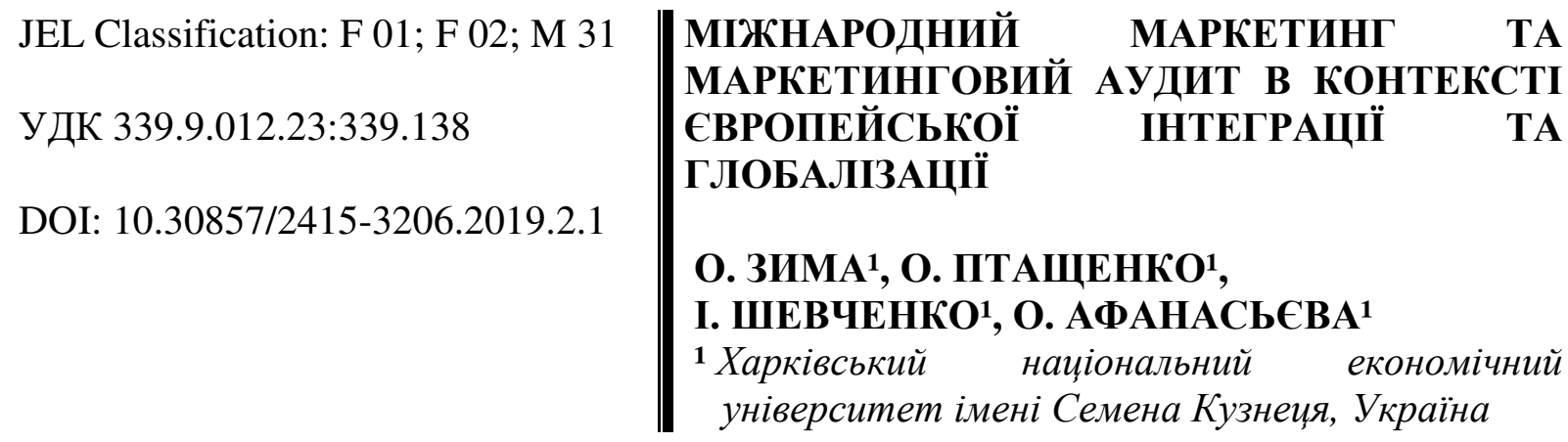

Вступ: Особливості міжнародного маркетингу визначаються специфікою зовнішнього середовища, в умовах якої він реалізується. Перш за все необхідно враховувати ставлення національного уряду до зовнішньоекономічної діяльності. Воно може створювати сприятливі умови для здійснення зовнішньоекономічної діяльності. I навпаки, уряд може бути незацікавленим у виході окремих своїх фірм на зовнішній ринок, може створити всілякі перешкоди на цьому шляху. Для маркетингу в цілому та для міжнародного маркетингу сьогодні характерне швидке старіння ідей і концепцій, викликане змінами ринкової ситуації. А система управління компанією інерційна: маркетингові стратегії, методи і прийоми, які застосовувалися вчора, застосовуються і сьогодні. Тому корисно залучати сторонніх фахівців для проведення маркетингового аудиту, що дозволяе поновому поглянути на звичні обставини i умови, привнести нові ідеї і відкрити нові можливості.

\section{Гіпотеза наукового дослідження.}

Передбачається, що процеси глобалізації мають суттєвий влив не тільки на розвиток міжнародного маркетингу, ай на маркетинговий аудит, що в свою чергу дає змогу визначити особливості міжнародного маркетингу.

Метою статті є дослідження сутності міжнародного маркетингу та маркетингового аудиту, представлено основні їх характеристики та принципи взаємодії в сучасних умовах господарювання.

Методи дослідження: метод системного аналізу та логічного узагальнення - для імплементація напрямів розвитку міжнародного маркетингу; субстратний підхід - для обгрунтування та систематизації особливостей міжнародного маркетингу та маркетингового аудиту.

Результати: обгрунтовано особливості міжнародного маркетингу та маркетингового аудиту, це дає змогу оцінити діяльність підприємства в сфері маркетингу та міжнародного маркетингу, порівняти отримані дані про маркетингову діяльність підприємства на внутрішньому та зовнішньому ринках 3 підходом до маркетингу прямих конкурентів, розробити рекомендації щодо підвищення ефективності роботи маркетингового підрозділу на підприємстві, щодо застосування сучасного інструментарію маркетингу та особливостей міжнародного маркетингу i визначити алгоритм їх реалізації, щоб відповісти на нові вимоги ринку i конкурентної ситуації, оцінити ефективність діючого персоналу служби маркетингу, прийняти кадрові рішення, визначити якісні та кількісні потреби в персоналі.

\section{Висновки: питання проведення} маркетингового аудиту в сьогоднішніх умовах функціонування підприємств має першочерговий характер. Його необхідність полягає в визначенні ефективності існуючих методів управління, а також вироблення нових підходів до створення комплексу маркетингу в рамках стратегії підприємства, що діє в умовах евроінтеграційних та глобалізацій них процесів.

Ключові слова: маркетинг; міжнародний маркетинг; маркетинговий аудит; аудит маркетингу. 
Formulation of the problem. At the present stage of the development of society, the assertion that in today's world knowledge and information generate new knowledge, their volumes and influence on the productive development of society is constantly growing. This challenge demands from modern society new ways and means of dissemination and use of global knowledge for the purpose of further progress, which is the main property of the society of knowledge and information. The search for a new paradigm of world order, requiring the globalization of knowledge and scientific achievements, and became a prerequisite for the emergence of a new phase of human development, associated with the advent of the information society and its most advanced form - a knowledge society. That is why today, in the era of the information society, mankind receives a powerful tool for combining efforts to acquire new knowledge aimed at solving their global problems, economic growth and raising the living standard of the population.

The process of globalization in the economy is manifested in the following: increasing the volume of world trade in goods and services; mobility of the movement of capital and labor is ensured; there is a merger of markets, organizations and production chains; state borders become more transparent for economic activity. Globalization affects all spheres of human life and has a significant impact on the activities of international organizations and national governments. Globalization processes are also observed in science. So for the present time, many studies are conducted by international teams on an integration basis, while national state borders are erased, scientific results become more and more global in nature.

Thus, under the influence of globalization, there is a change in all aspects of society's life. This process is large-scale, becoming the subject of study of almost all public scientific disciplines.

That is why, today, the development of information technology has become one of the main factors for the development of the global community and the acceleration of the globalization process. Communication subjects have a direct influence on the communicative space in the current globalization environment in the form of the general informational environment that was formed in the process of information exchange, but also through means of communication established in a particular social-psychological environment rules of communication, moral norms of interaction, customs and traditions, speech rituals, etc. The interconnections of the participants in the international communicative process with the communicative space are expressed, first, in the direct connection and constant dependence between them, which affects the system of coding and decoding of the signs, the content of the message; secondly, the purposeful influence of the subjects of communication on the communicative space and the latter on them, which causes changes and 
development of each of them; third, in the emergence of contradictions between the communicative space and the person in the absence of conditions for it to meet the information needs of the person; Fourth, in the emergence in the communicative space of processes and mechanisms that promote or not promote mutual understanding between the actors of the information chain; fifth, the influence of the communicative process on the communicative space and vice versa, which leads to changes in each of them; sixth, in the emergence of contradictions between the participants in the communicative process and the communicative space in the absence of the last conditions for the effective exchange of information, the establishment of mutual understanding and dialogue $[1-4,8-12]$.

Philip Kotler [8] defines marketing as a kind of human activity aimed at meeting needs through exchange. Peter Drucker formulated the main goal of marketing - to make unnecessary sales efforts, his goal is to so well know and understand the customer that the product or service will fit the latter and match it to yourself.

In this case, according to Rick Cranndell, marketing should combine any action aimed at acquiring or retaining a client. Very similar opinion, but at the level of evolutionary processes, Anatoly Matveyev adheres to the definition of marketing in terms of the tools of evolution in the market.

Marketing represents today a set of different components of the market system (Figure 1).

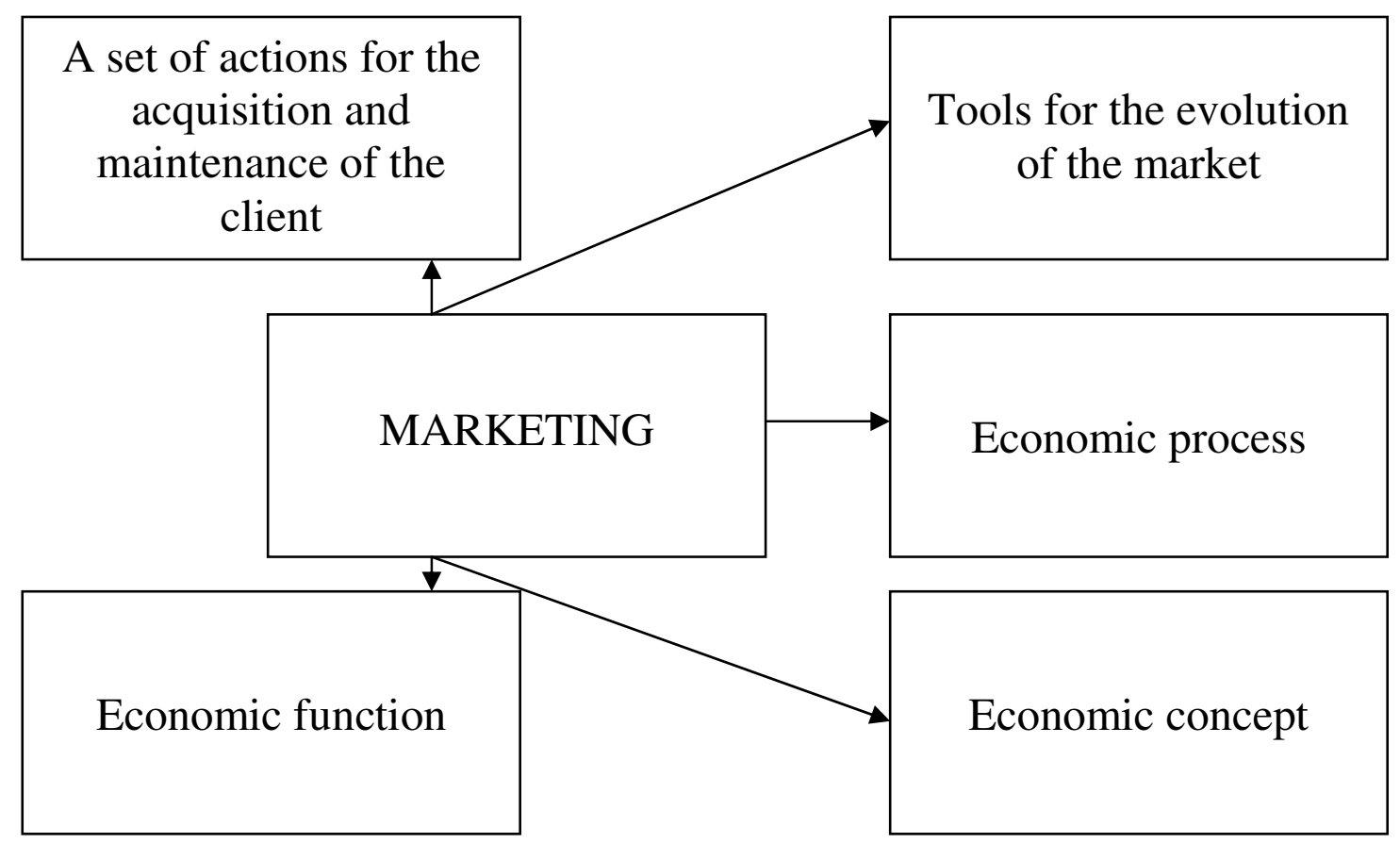

Source: compiled by the authors.

Figure 1. The essence of marketing 
From the above analysis, one can see that there are not many similar interpretations. Each scientist shows his understanding of this concept and they are diverse. Therefore, the only conclusion to this can be that marketing in the enterprise is in a sense a philosophy of production and business.

A special role in the organization of marketing at the enterprise belongs to the analytical function, which primarily involves the study and analysis of the marketing environment. The importance of this function is due to the fact that the quality of marketing information about the external and internal environment of the business entity is crucial for the adoption of reasoned managerial decisions.

Traditional forms and methods of managerial control, operating under the command and administrative system, were incapable of meeting new information needs of management of business entities, business owners, creditors, investors and other information consumers. All this stimulated the introduction of an independent form of preventive control - marketing audit, when the marketing environment of the enterprise with in-depth diagnostics of all components of the marketing system of the enterprise was investigated. Consequently, marketing audit as a kind of control involves systematic, complex and independent evaluation and analysis of the main factors of the enterprise environment, conducting situational (marketing) analysis of its internal state. Based on these results, reasonable measures are being developed to improve the effectiveness of the marketing activities of the enterprise as a whole and its individual business units. In this regard, the study of methodological aspects of organizing and conducting marketing audits is a topical scientific and practical problem.

That is why in today's development of the society the special attention is paid not only to the most modern concept of marketing, but also to the possibility of using modern marketing tools in international markets. In the marketing of international markets, the principles of foreign economic activity are laid down and a separate stratum of international marketing is formed. At the same time control function under such conditions of development may be put on a marketing audit, as a new form of independent management control.

Analysis of recent research and unresolved part of the problem. Many Ukrainian and foreign authors like G. Asssel, Ph. Kotler, G. Bagiyev, V. Tarasevich, H. Ann, M. McDonald, J.-J. Lamben, N. Kudenko, I. Reshetnikova and others. Features of the development and implementation of marketing strategy in high-tech markets and certain aspects of integration of technological and marketing strategy at the enterprise were identified by I. Ansoff, N. Fonstein, M. Asmolov, T. Douglas Braunlay and Douglas K. Macbeth, D. Ford, N. Chukhray and others. 
Fundamental problems of the development of the management system of international marketing are highlighted in the writings of foreign scientists K. Bartlett, S. Groshall, J. Danieles, F. Cateàori, M. Porter, L. Radenbau, P. Rivoli, I. Ronkainin, A. Saidenbegha, L. Hoffmann, M. Chinkoti, K. Schmittchaff. The specifics of the implementation of individual instruments of international marketing are devoted to the work of D. Aaker, S. Akter, T. Ambleer, J. Graham, S. Jane, J.-P. Janet, R. Kevin, V. Kirpalani, D.N. Lucky, T. Melon, J. O'Honnesy, R. Peterson, C. Stiles, B. Toin, P. Walters, H. Hennesy, S. Hollensen. Detailed functions of internationalized marketing activities are investigated by G. Armstrong, K. Barnett, S. Douglas, Ph. Kotler, S. Craig, V. Puchik, N. Tichi, D. Watervortom, and others.

Functional manifestations of international marketing were investigated in the works of O. Azaryan, A. Voichak, V. Kardash, A. Kredisov, E. Kricavsky, A. Mazaraki, Y. Makogon, L. Moroz, V. Onischenko, V. Pelishenko, P. Perervi, G. Pocheptsova, I. Reshetnikova, E. Romat, E. Savelieva, A. Starostina, N. Chukraj, T. Tsigankova and others.

So, Philip Kotler [11-12] defines international marketing as a comprehensive study of the current and future needs of foreign markets, the system of planning, organization and management of the transnational corporation in the context of scientific research and design (design) of new types of goods, their production, purposeful formation of consumer demand and marketing of manufactured products from the purpose of effective provision of long-term interests and appropriation on this basis of maximum and stable profits.

In this case, S. Madjaro [5] defines international marketing on the part of systematic, continuous, active work in the international market at various stages of the advancement of commodity products and services to the consumer.

B. Golubkov [6] bases its definition of international marketing on the assumption that world markets have differences, and the most effective strategies take it into account.

The works of foreign and domestic scholars are devoted to the research of dynamic changes in the market environment, the timely adaptation of business entities' strategies for future changes, as well as the essence and conceptual models of marketing: R. Alexander, I. Ansoph, G. Armstrong, B.B. Berman, D. Gelbright, B. Grossa, P. Doyl, P. Drucker, Ph. Kotler, J.M. Keynes, T. Levit, A. Maslow, J.-J. Lamben, M. Porter, H. Hershagen, L. Festinger, A.F. Pavlenko, A.V. Voychak, V.Ya. Kardash, N.V. Kudenko, V.G. Gerasimchuk, T.I. Lukyanets, S.S. Harkavenko, T.B. Reshetylova and other.

However, the problems of marketing audit are considered only fragmentarily, without sufficient development of methodological bases, which served as the basis for choosing the topic of the dissertation research. 
The aim. The presented work is aimed at theoretical and analytical consideration of the process of conducting international marketing and marketing audit in the current conditions of European integration and globalization in Ukraine and in the world. The article discusses the essence of international marketing and marketing audit, presents their main characteristics and principles of interaction in modern economic conditions.

Research results. The peculiarities of international marketing of the present are determined by the specifics of the external environment in which it is implemented. First of all, it is necessary to take into account the attitude of the national government to foreign economic activity. It can create favorable conditions for the implementation of foreign economic activity. On the contrary, the government may be uninterested in the output of individual companies or companies on the external market, may create all kinds of obstacles on this path. For the most part, national governments are encouraging exports and, if possible, seek to reduce imports. Therefore, they tend to facilitate the implementation of foreign economic activities by national enterprises (companies). In turn, the importing country can provide the most favorable conditions for the foreign firms' business in their territory, and vice versa, create all kinds of barriers to entry into its market. Favorable conditions are usually ensured in the supply of scarce primary goods or high technology, and obstacles arise when national enterprises produce enough goods individually.

The essence of international marketing will be presented in Figure 2.

So, according to Philip Kotler, international marketing is determined by the fact that since national (internal) marketing has arisen and developed internationally, the strategies, principles and methods used in it, principles and methods are also characteristic for international marketing. At the same time, when entering the international market, the firm can no longer be limited to the use of only marketing tools already developed by it, even subject to a certain modification.

When entering the international market, the firm faces strangers that change depending on the specifics of the country with different conditions of activity. This leads to the following consequences [15]:

increasing the need for information security of the company;

increase of requirements for coordination of various spheres of activity of the firm and coordination of actions of various subdivisions thereof;

increase in the level of overall risk, the appearance of additional types of risks in the activities of the company.

Thus, international marketing is an independent branch of the firm's activity when it enters external markets, which can be defined as follows. 


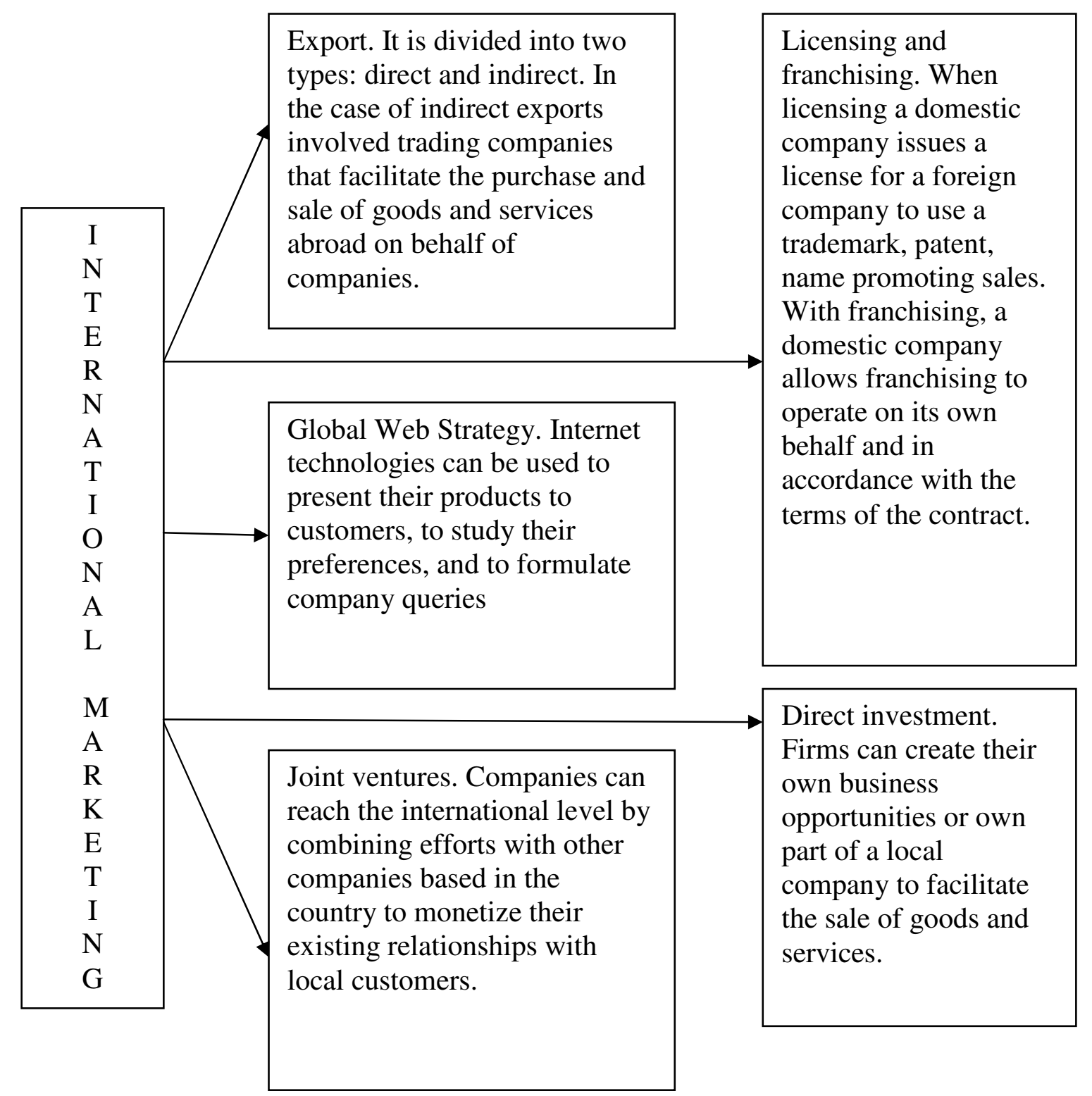

Source: compiled on the basis of sources $[1-5,8,10,15,17-18]$

\section{Figure 2. The essence of international marketing}

International marketing - a ystem of planning, implementation, control and analysis of measures to influence the multinational market environment and adaptation to its conditions in a company that operates in more than one country.

Briefly and generalized, international marketing can be defined as a complex of measures of the company for the implementation of foreign economic activities outside its own country.

In the development of international marketing, we can distinguish three main stages (Figure 3). 


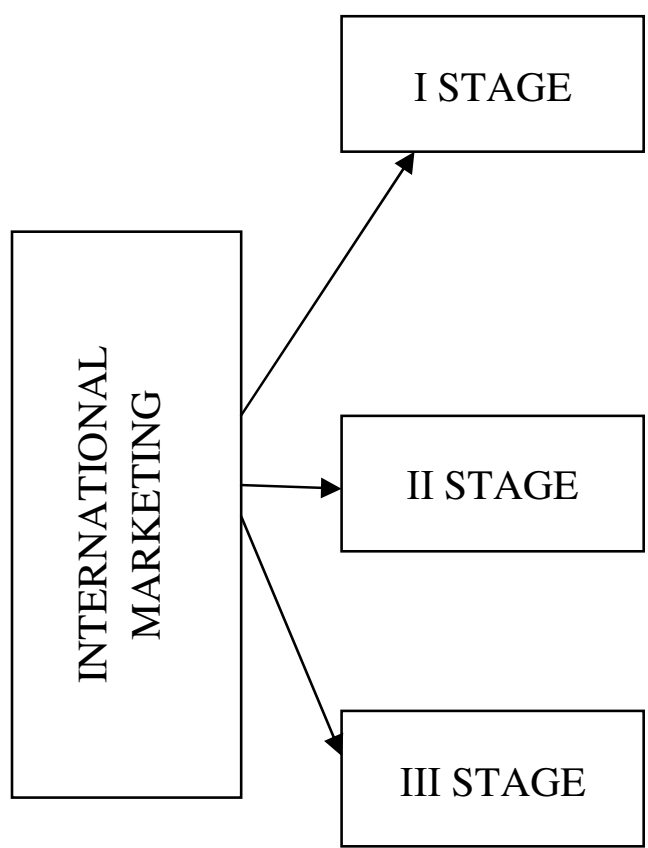

Traditional marketing is the usual sale of goods abroad, where the exporter is liable to the buyer only at the time of delivery and, as a rule, is not interested in the subsequent share of the product sold.

Export marketing. The exporter is engaged in the systematic study of the target foreign market and adapts its production to the requirements of changing this market.

International marketing. Exporter deeply explores the market and uses a wide range of marketing tools for this.

Source: compiled on the basis of sources [8-12, 14, 16, 19-21].

\section{Figure 3. Stages of international marketing}

International marketing extends not only to purely trade operations but also to other areas of foreign economic relations: the creation of joint and subsidiary enterprises, scientific and technical exchange, transfer of licenses and knowhow, provision of transport, insurance, tourist and other services; international leasing operations, etc.

The modern model of international marketing can be conventionally called production and investment (as opposed to the former - trade and intermediary). She has undergone qualitative changes, has risen to a higher level. International marketing is now increasingly seen not only as an international or multinational, but also as a global one.

Consequently, international marketing is an approach to making manufacturing decisions from the point of view of the most complete satisfaction of the requirements of both local and foreign consumers. The parent company purposefully assigns tasks to its production units - local and foreign with respect to scientific and technical developments and products, which determines the most efficient production technology, including inter-firm and domestic brand cooperation. Here an important role is played by marketing 
programs developed in the structural subdivisions of the parent company production departments, which appear as the main production and economic units responsible for the final result of the activity - profit, folk activity of firms and is a prerequisite for planning the production of the company as a whole, since they give the possibility to establish an optimal structure (nomenclature, assortment) of production. As a result of marketing activity and on the basis of it, international business cases and commercial operations are conducted.

To ensure the high efficiency of operation at the international level, enterprises need to continuously and continuously monitor the market through market research. It is thanks to information from these studies that managers have the ability to respond quickly to market changes and make appropriate management and marketing decisions.

The globalization of international marketing activities is related to the interdependence of the Triad countries, whose economic, socio-cultural and political-legal environment is becoming more and more homogeneous. There are supranational segments that increase the market opportunities of the enterprise.

The means of solving marketing problems that arise in connection with the emergence of new priorities are the strengthening of new strategic approaches to the formation of a marketing complex.

The catalyst of Euro-regional cooperation of domestic enterprises should be state and international marketing. State policy by its economic levers regulates unfair competition from other countries, and international marketing offers new methods of promoting products to world markets and a reproductive mechanism of the international economy.

For marketing characterized by rapid aging of ideas and concepts caused by changes in market situation. And the company's management system of inertia: the marketing strategies, methods and techniques that were used yesterday, are applied today. Therefore, it is useful to engage third-party professionals to conduct marketing audits (marketing audits), which allows you to take a fresh look at the usual circumstances and conditions, bring new ideas and discover new opportunities. Often, experts are attracted not so much to audit, but to create new approaches to marketing, or to form (reorganize) a marketing mix within the company's existing strategy.

Marketing audit should be understood as a competent, independent, periodic and comprehensive study of the main factors of the external and internal environment, objectives, strategies and activities of the enterprise in order to prevent detection of problems and hidden potential, as well as the development of an adequate marketing strategy. It serves as an analytical tool for identifying, measuring, evaluating, motivating and implementing the necessary actions to achieve the best results, as well as the confidence that all 
sources and factors are fully identified and used as much as possible. Contents of the expanded marketing audit is presented in Figure 4.

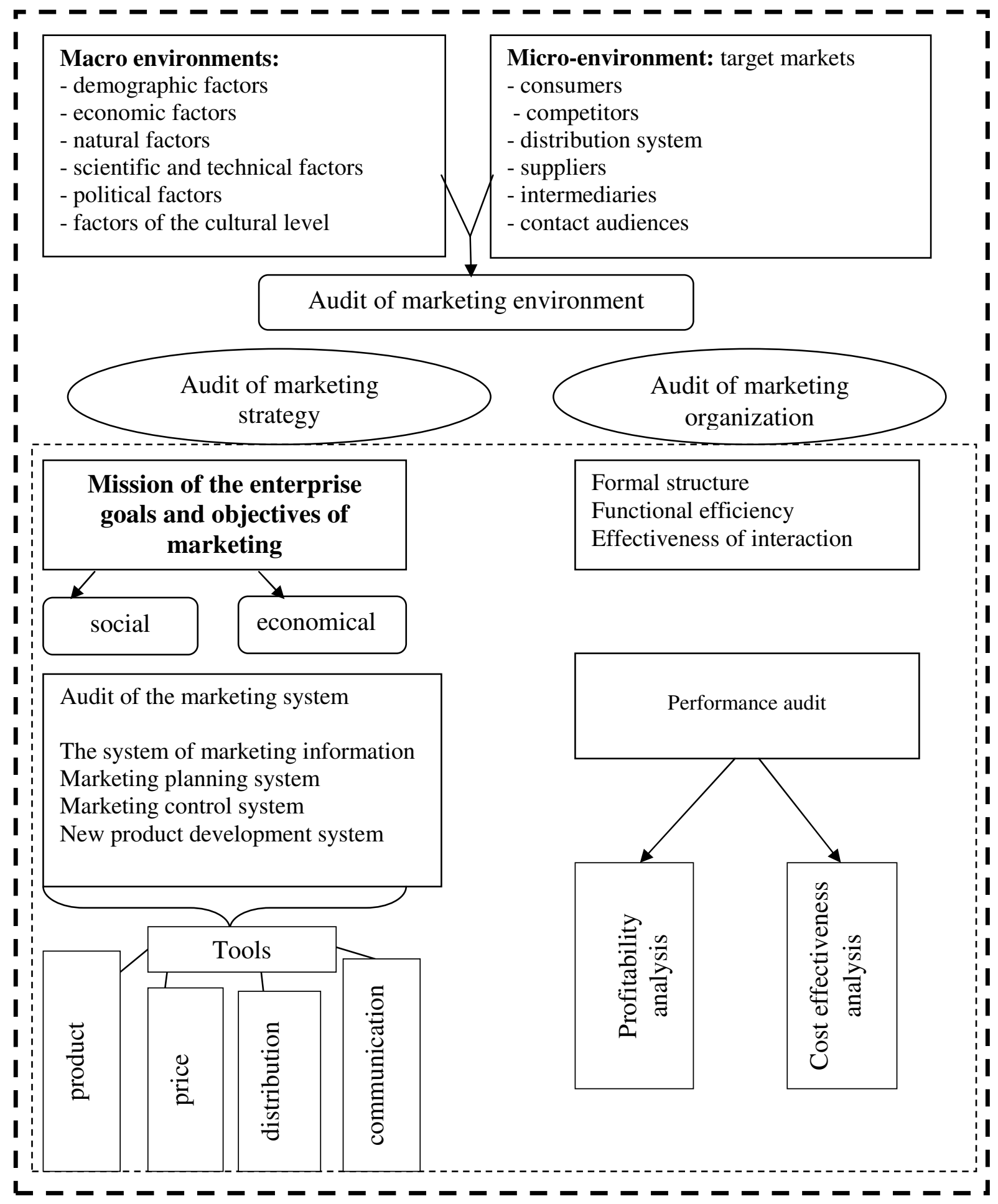

Source: compiled by the authors.

Figure 4. Content of the marketing audit 
The main objectives of marketing audit include: preventive detection of the inconsistency of the state of the product offering of the enterprise to the requirements of its market environment, the development of recommendations for reducing possible differences caused by the peculiarities of the market situation, the specific functioning of the producer, resources, goals, etc.

Since the internal environment of each enterprise is individual, as well as positioning in the market, the task of marketing audit, its methods and actions are also not deprived personification.

Marketing audit as a kind of strategic control is aimed at ensuring the achievement of perspective goals of the enterprise, increasing the effectiveness of marketing, informs about the need to make changes in the future, increases the chances of increasing the competitive advantages in the national and international economy. In contrast, operational marketing-control is directed only at the regulation of intermediate indicators and their evaluation in order to optimize profits. If operational control of marketing involves costs and income, then strategic control deals with indicators of risk and potential success.

In the face of radical changes in the environment that may lead to changes in the set goals, development models, significant adjustments to adopted plans and programs, each enterprise, aimed at achieving long-term success in the market, should systematically carry out preventive critical analysis and evaluation of the effectiveness of marketing activities.

The marketing audit process is inseparable from the marketing management process at the enterprise, and its implementation is one of the sections of the overall business plan. On Figure 5 the process of marketing audit in the management system of a modern enterprise.

Thus, based on the marketing audit, reasonable measures are being developed to improve the efficiency of the management activity of the enterprise as a whole and its separate economic units.

Marketing audit allows $[12,15]$ :

- identify problems with the functioning of the marketing service, leading to loss of efficiency;

- to provide significant savings in financial, human and time resources by adjusting marketing strategy.

It is therefore possible to assert that marketing audit is an important part of the marketing management process. According to the results of the audit and based on the data received, the general marketing strategy is adjusted, profitability and long-term survival of the company are ensured.

To make strategic decisions and develop a successful strategy, you need a comprehensive vision of the situation. Therefore, when conducting a marketing audit it is necessary to receive data from different sources. 


\section{The stage of preliminary preparation of marketing audit}

first contact with senior management of an enterprise with the aim of developing an agreement on objectives, range, depth, sources of information, type of final report, duration of audit; development of a task-plan on the basis of a preliminary analysis of the problem; negotiation and conclusion of a contract for advisory assistance.

The second stage. Diagnostic examination
provides for the definition of the existing state of the enterprise by collecting and
storing various information (this consumes most of the time of the auditor) and its
careful analysis.

The third stage. Analysis and processing of information
the conclusions are drawn on the success of the implementation of interconnected and
interacting elements of the marketing complex.
Fourth stage. Recommendations development
has the purpose of finding solutions for the loss of profit from unrealized actions or
the absence of an enterprise marketing strategy (program). An important aspect of
this stage is the direct involvement of managers and specialists of the company in
discussing, evaluating and developing the concept of marketing.

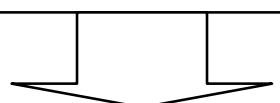

The fifth stage. Preparation, approval and presentation of the report

at this stage, the results of research, surveys, observations and most of the proposals developed during the audit are intended to convince the customer to accept them for the audit result, and logical illustrated and formalized calculations and explanatory recommendations contribute to this.

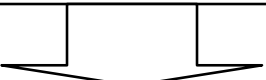

The sixth stage. Implementation and maintenance of results

provides for the preparation and implementation of a plan of measures for the implementation of accepted proposals and recommendations, marketing strategy of the enterprise. At this stage, the auditor can accompany the implementation of the plan of planned actions in the form of advising senior management and training specialists of the relevant divisions of the enterprise.

Source: compiled by authors on the basis of sources [10-12].

Figure 5. Process of marketing audit of the enterprise 
Conclusions and suggestions. Globalization of economic ties covers various areas of international economic relations and markets, including the technology market (from high-tech and to information). Therefore, under such conditions of the development of the world economy, the attraction of technologies is considered as one of the main factors of the growth of the economy as transformational countries and developed. The study of the international market of modern technologies, in particular evolution processes, the formation of elements and their structure, is a topical issue of the present. Active participation in the international technology market is a key to gaining access to advanced knowledge, to stimulate domestic innovation, and to increase the productivity of economic processes.

Thus, marketing allows to evaluate the activity of the company in the field of marketing and international marketing, compare the obtained data on the marketing activities of the company in the domestic and foreign markets with the approach to marketing of direct competitors, to develop recommendations for improving the efficiency of the marketing unit at the enterprise, the use of modern marketing tools and features of international marketing and determine the algorithm of their implementation to meet the new market demands and onkurentnoyi situation, evaluate the effectiveness of the existing staff of marketing, take personnel decisions, to determine the qualitative and quantitative staffing requirements.

\section{References}

1. Azoyev, G.L., Bykova, M.K. (2013). 3D-model prodvizheniya nanotekhnologicheskikh innovatsiy [3D-model of the advancement of nanotechnological innovations]. Marketing i marketingovyye issledovaniya [Marketing and marketing research], No. 5, P. 370-382 [in Russian].

2. Bozhkova, V., Ptashchenko, O., Sager, L., Sigida, L. (2018). Transformatsii instrumentariya marketingovykh kommunikatsiy $\mathrm{v}$ usloviyakh globalizatsii [Transformations of marketing communications tools in the context of globalization]. Marketing i menedzhment innovatsiy [Marketing and innovation management], No. 1, P. 73-82 [in Ukrainian].

3. Dracheva, Ye.L., Zabayev, Yu.V., Ismayev, D.K. et al. (2007). Economics and organization of tourism: international tourism: training. Moscow: Knorus. 576 p. [in Russian].

\section{Література}

1. Азоев Г. Л. 3D-модель продвижения нанотехнологических инноваций / Г. Л. Азоев, М. К. Быкова // Маркетинг и маркетинговые исследования. 2013. - № 5. - C. 370-382.

2. Божкова В. В. Трансформації інструментарію маркетингових комунікацій в умовах глобалізації / В. В. Божкова, О. В. Птащенко, Л. Ю. Сагер, Л. О. Сигида // Маркетинг і менеджмент інновацій. 2018. - № 1. - C. 73-82.

3. Экономика и организация туризма: международный туризм: учебное пособие / Е. Л. Драчёва, Ю. В. Забаев, Д. К. Исмаев и др.; под ред. И. А. Рябовой, Ю. В. Забаева, Е. Л. Драчёвой. - 4-е изд., испр. и доп. - М.: КНОРУС, 2013. - 576 c. 
4. Hinner, M.B. (1998). The importance of intercultural communication in globalized world. Retrieved from: http://www.bwl.tuFreiburg.de/english/forschung/Global/pdf.

5. Kanishchenko, O.L. (2007). Metodolohichni aspekty mizhnarodnoho marketynhu [Methodological Aspects of International Marketing]. Visnyk KNU. Seriya Ekonomika [Bulletin of KNU. Series: Economics]. Vol. 93. Kyiv: VPTS Kyyivskyy universytet. P. 43-46 [in Ukrainian].

6. Kanishchenko, O.L. (2007). Mizhnarodnyy marketynh u diyalnosti ukrayinskykh pidpryyemstv [International marketing in the activity of Ukrainian enterprises: a monograph]. Kyiv: Znannya. 448 p. [in Ukrainian].

7. Kichurchak, M.V. (2015). Teoretykometodolohichni determinanty mekhanizmu vidtvorennia suspilnykh blah [Theoretical and methodological determinants mechanism of reproduction of public goods]. Economic AnnalsXXI, No. 3-4 (2), P. 8-11 [in Ukrainian].

8. Kotler, Ph. (2006). Marketing menedzhment. Ekspress-kurs [Marketing management. Express course]. Trans. from English. Eds. S. G. Bozhuk. 2nd ed. St. Petersburg: Piter. 464 p. [in Russian].

9. Kotler, Ph., Kotler, M. (2015). Winning Global Markets: How Businesses Invest and Prosper in the World's High Growth Cities. Wiley.

10. Kotler, Ph., Keller, K., Shamma, H.M. (2012). Marketing Management (Arab World Edition). Upper Saddle River: Pearson Higher Education.

11. Kotler, Ph., Berger, R., Bickhoff, N. (2010). The Quintessence of Strategic Management. New York: Springer.

12. Kotler, Ph., Shalowitz, J., Stevens, R. (2008). Strategic Marketing for Health Care Organizations: Building a Customer-Driven Health Care System. Indianapolis, IN: JosseyBass.

13. Osnovni formy i napryamky mizhnarodnoho kul'turnoho obminu na rubezhi XX-XXI st. [The
4. Hinner M. B. The importance of intercultural communication in globalized world / M. B. Hinner. - 1998. - Retrieved from: http://www.bwl.tuFreiburg.de/english/forschung/Global/pdf. 5. Каніщенко О. Л. Методологічні аспекти міжнародного маркетингу / О. Л. Каніщенко // Вісник КНУ. Серія: Економіка. - Вип. 93. - К.: ВПЦ "Київський університет", 2007. С. 43-46.

6. Каніщенко О. Л. Міжнародний маркетинг у діяльності українських підприємств: монографія. - К.: Знання, 2007. - 448 c.

7. Кічурчак М. В. Теоретикометодологічні детермінанти механізму відтворення суспільних благ / M. В. Кічурчак // Economic AnnalsXXI. - 2015. - № 3-4 (2). - P. 8-11.

8. Котлер Ф. Маркетинг менеджмент. Экспресс-курс / Ф. Котлер; пер. с англ. под ред. С. Г. Божук. - 2-е изд. - СПб.: Питер, 2006. - 464 с.

9. Kotler Ph. Winning Global Markets: How Businesses Invest and Prosper in the World's High Growth Cities / Ph. Kotler, M. Kotler. - Wiley, 2015.

10. Kotler Ph. Marketing Management (Arab World Edition) / Philip Kotler, Kevin Keller and Hamed M. Shamma. Upper Saddle River: Pearson Higher Education, 2012.

11. Kotler Ph. (2010). The Quintessence of Strategic Management / Philip Kotler, Berger Roland and Nils Bickhoff. - New York: Springer, 2010.

12. Kotler Ph. Strategic Marketing for Health Care Organizations: Building a Customer-Driven Health Care System / Philip Kotler, Shalowitz Joel and Robert Stevens. - Indianapolis, IN: Jossey-Bass, 2008.

13. Основні форми i напрямки міжнародного культурного обміну на 
main forms and directions of international cultural exchange at the turn of the XX-XXI centuries]. Retrieved from: https://studfiles.net/preview/ 3197608/page:25 [in Ukrainian].

14. Nardiello, G.G., Naumik-Gladka, K., Ptashchenko, O., Maliukina, A. (2017) Economic development based on international enterpreneurship and business tourism. Economic Annals-XXI (2017), No. 165(5-6), P. 104-109.

15. Pechulyak, Yu.S., Iksarova, N.O. (2015). Osoblyvosti upravlinnya mizhnarodnym marketynhom na vitchyznyanykh pidpryyemstvakh [Features of Management of International Marketing at Domestic Enterprises]. Visnyk Pryazovskoho derzhavnoho tekhnichnoho universytetu: $\mathrm{zb}$. naukovykh prats [Bulletin of the Azov State Technical University: a collection of scientific papers], Vol. 30, P. 325-332 [in Ukrainian].

16. Ponomarenko, V., Gontareva, I., Dorokhov, O. (2014). Statistical testing of key effectiveness indicatorsof the companies (Case for Ukraine in 2012). Ikonomicheski Izsledvania (Economic Studies), Vol. 23, Issue 4, P. 108-124.

17. Ptashchenko, O.V. (2018). Mizhnarodnyy marketynh vysokykh tekhnolohiy ta yoho vzayemozvyazok z intehratsiyeyu ta hlobalizatsiyeyu [International high-tech marketing and its relationship with integration and globalization]. Visnyk Kyivskoho natsionalnoho universytetu tekhnolohii ta dyzainu Seriia: Ekonomichni nauky [Bulletin of the Kyiv National University of Technologies and Design], No. 3 (122), P. 68-78 [in Ukrainian].

18. Ptashchenko, O.V. (2017). Osoblyvosti rozvytku mizhnarodnoho marketynhu vysokykh tekhnolohiy $\mathrm{v}$ umovakh hlobalizatsiyi [Features of development of international marketing of high technologies in the conditions of globalization]. Visnyk Kyivskoho natsionalnoho universytetu tekhnolohii ta dyzainu Seriia: Ekonomichni nauky [Bulletin of the Kyiv National University of Technologies and Design], No. 2 (121), P. 72-81 [in Ukrainian].

19. Tarasenok, A.I. (2012). Marketing turistskikh destinatcii $\mathrm{v}$ kontekste dialoga kultur [Tourism рубежі XX-XXI ст. [Електронний pecypc]. - Режим допуску: https:// studfiles.net/preview/3197608/page:25.

14. Nardiello G. G. Economic development based on international enterpreneurship and business tourism / G. G. Nardiello, K. Naumik-Gladka, O. Ptashchenko, A. Maliukina // Economic Annals-XXI. 2017. - No. 165 (5-6). - P. 104-109.

15. Печуляк Ю. С. Особливості управління міжнародним маркетингом на вітчизняних підприємствах / Ю. С. Печуляк, Н. О. Іксарова // Вісник Приазовського державного технічного університету: зб. наукових праць / ПДТУ (Маріуполь). - 2015. Вип. 30. - С. 325-332.

16. Ponomarenko V. Statistical testing of key effectiveness indicatorsof the companies (Case for Ukraine in 2012) / V. Ponomarenko, I. Gontareva, O. Dorokhov // Ikonomicheski Izsledvania (Economic Studies). - 2014. - Vol. 23, Issue 4. - P. 108-124.

17. Птащенко О. В. Міжнародний маркетинг високих технологій та його взаємозв'язок 3 інтеграцією та глобалізацією / О.В. Птащенко // Вісник Київського національного університету технологій та дизайну Серія: Економічні науки = Bulletin of the Kyiv National University of Technologies and Design. - 2018. № 3 (123). - C. 68-78.

18. Птащенко О. В. Особливості розвитку міжнародного маркетингу високих технологій в умовах глобалізації / О. В. Птащенко // Вісник Київського національного університету технологій та дизайну = Bulletin of the Kyiv National University of Technologies and Design. Cepiя: Економічні науки. - 2018. - № 2 (121). - C. 72-81.

19. Тарасенок А.И. Маркетинг туристских дестинаций в контексте 
Destination Marketing in the Context of Cultural Dialogue]. Materialy V Mizhnarodnoyi naukovopraktychnoyi konferentsiyi "Turyzm ta zblyzhennya kultur" (Proceedings of the V International scientific conference "Tourism and convergence of cultures"). Kyiv University of Tourism, Economics and Law. Part 1, P. 20-34 [in Russian].

20. Huntington, S. Zitknennia tsyvilizatsii [The Clash of Civilizations]. Retrieved from: http://lib.chdu.edu.ua/pdf/posibnuku/307/36.pdf [in Ukrainian].

21. Tsentr komunikatyvnykh transformatsiy [Center for Communicative Transformations]. Kyiv-Mohyla Academy. Retrieved from: http://www.ukma.edu.ua/index.php/science/ tsentri-ta-laboratoriji/tsentrkomunikativnikhtransformatsi [in Ukrainian]. диалога культур / А. И. Тарасенок // Матеріали V Міжнародної науковопрактичної конференції «Туризм та зближення культур» (м. Київ, 3 листопада 2011 р.): в 2 ч. - К.: Київский університет туризму, економіки та права, 2012. - Ч. 1. C. 20-34.

20. Хантінгтон C. Зіткнення цивілізацій [Електронний ресурс]. Режим доступу: http://lib.chdu.edu.ua/ pdf/posibnuku/307/36.pdf.

21. Центр комунікативних трансформацій [Електронний ресурс] / Києво-Могилянська академія. - Режим доступу: http://www.ukma.edu.ua/index. $\mathrm{php} / \mathrm{science} /$ tsentri-ta-laboratoriji/ tsentrkomunikativnikh-transformatsi. 